\title{
Oralidade e Poesia Oral: paradigmas para a definição de uma oratura grega antiga
}

Robert de Brose ${ }^{1}$

\begin{abstract}
Resumo: Neste artigo discutirei as principais contribuições a uma poética da oralidade que levam em conta a produção, disseminação, e recepção da poesia oral sem vê-la como um subtipo da literatura escrita. Irei argumentar que, como demonstram vários estudos, alguns dos quais aqui discutidos, a poesia oral não se define nem como oposta nem como subordinada à poesia escrita, mas, sobretudo, por um sistema cognitivo e conceitual distinto, capaz de gerar textos que, mesmo escritos, preservam características típicas de obras vocais. Através de paradigmas oriundos de outras culturas, tanto antigas quanto modernas, e de estudos de cunho etnológico e linguístico, irei argumentar da vantagem de se reconhecer na literatura grega antiga uma oratura, isto é, um corpus literário marcado por uma oralidade conceitual primária ou secundária.
\end{abstract}

Palavras-chave: oralidade; poesia oral; performance; recepção; poesia grega.

Abstract: In this article I shall discuss the main contributions to a poetics of orality that consider the production, dissemination, and reception of oral poetry by not framing it as a subtype of written literature. I shall argue that, as several studies have shown, some of which discussed here, oral poetry does not need to be defined as opposed or subordinated to written poetry, but, rather, by a distinct cognitive and conceptual system capable of generating texts that, even when written, preserve defining features of conceptually oral texts. By drawing paradigms from other cultures, both ancient and modern, and by referring to ethnological and linguistic studies, I shall argue for the advantage of recognising in ancient Greek literature an "orature", that is, a literary corpus marked by features of a conceptual, either primary or secondary, orality.

Keywords: orality; oral poetry; performance; reception; Classical antiquity.

Le désir de la voix vive habite toute poésie, en exil dans l'écriture. Paul Zumthor, Introduction à la Poésie Orale.

1 Doutor em Letras Clássicas pela Universidade de São Paulo (USP). Professor Adjunto de Letras Clássicas e Tradução da Universidade Federal do Ceará (UFC). Integra o Programa de Pós-graduação em Estudos da Tradução POET/UFC. 


\section{Introdução}

Como já foi apontado por Rosalind Thomas², "oral” é um termo propenso à ambiguidade, mas que se define principalmente pela sua oposição a "escrito" " Consequentemente, "oral" é todo tipo de transação ou ato de comunicação que aconteça sem a intervenção da escrita ou no qual ela tenha apenas um valor acessório. "Oralidade" (orality), segundo essa autora, foi um termo cunhado precisamente para se opor a literacia (literacy), que denota, em seu escopo mais limitado, o que chamaríamos de (a) "alfabetização", entendida como a capacidade de ler e escrever ${ }^{4}$, bem como a acepção sociocultural daquilo que (b) "é literato", ou seja, educado. Esta última acepção explicita a noção etnocêntrica difundida nas sociedades ocidentais de que a alfabetização, como definida em (a), é indispensável tanto para a obtenção da educação, quanto para a própria certificação do conhecimento e da ascensão ao status de "educado", o que é viabilizado pelo uso da escrita através de testes e exames.

A partir desse conceito estendido de "alfabetização"5 como um conjunto de habilidades que vão além do ler e do escrever, tem se tentado introduzir na língua portuguesa o uso dos termos "letramento" (Brasil) e "literacia" (Portugal) 6 , ambos decalcados, aliás, a partir do modelo do inglês "literacy" , embora ainda haja notável resistência à aceitação desses neologismos, sobretudo quando comparados ao termo "alfabetização" entanto, ao invés de competição entre ambos, talvez fosse mais profícuo reservá-los para realidades distintas. Acredito que "letramento", por ser um deverbativo construído a partir do sufixo "-ento", que em português mormente forma substantivos resultativos ou, em alguns casos, abstratos, seja mais adequado para o processo, o resultado e o fenômeno de aquisição das capacidades de lectoescritura, ao passo que "literacia", semelhantemente a

2 Thomas (1992), p. 6 seq.

3 Ainda que, num sentido mais amplo, o termo também possa ser usado para se referir a qualquer tipo de comunicação não-verbal, embora essa definição ampliada não nos interesse num primeiro momento. Sobre isso $c f$. Finnegan (2017 [1977]).

4 Em diferentes níveis de competência, um tópico que não caberia discutir aqui. Note ainda que o termo "lectoescrita" é um outro neologismo proposto por E. Ferreiro e A. Teberosky em Psicogênese da Língua Escrita (Artmed, 1999) como equivalente de literacy: ele pressupõe uma interrelação e a dependência mútua das duas capacidades, leitura e escrita.

5 A definição dessa palavra em português não explicita esse uso estendido. Em inglês a oposição é mais bem marcada: o contraste estabelecendo-se entre "literacy" e "illiteracy", para o que em português se diria "letramento" e "analfabetismo". Note, no entanto, que o vernáculo permite a distinção de dois níveis do termo marcado, aquele que diz respeito à habilidade de escrever ("letrado" x "iletrado") e o que diz respeito ao nível de envolvimento com a cultura escrita ("literato" x "iliterato").

6 "Letramento", segundo Magnani (2004), p. 40 seq., sobretudo por pertencer ao domínio técnico da pedagogia, não constava, até pouco tempo, dos principais dicionários da língua portuguesa como a $3^{\mathrm{a}}$ ed. do Aurélio (1999), a do Michaelis de1998, ou, ainda, a do Dicionário de usos do Português do Brasil de Francisco da Silva Borba, de 2002.

7 O Oxford Dictionary nota que literacy, datado do séc. XIX, foi formado a partir de literate ("having or showing education or knowledge, typically in a specified area"), sob o modelo de illiteracy.

8 Como a tradução de várias obras de referência do inglês para o português demonstra, há uma clara preferência em se traduzir literacy por "alfabetização", como, por exemplo no caso do livro de J. Cook-Gumpez, The Social Construction of Literacy (Cambridge University Press, 1986), vertido para o português como $A$ Construção Social da Alfabetização (Artes Médicas, 1991) ou o Literacy and Orality (Cambridge University Press, 1991), organizado por D. Olson e N. Torrance, cujo título nos chegou como Cultura Escrita e Oralidade (Ática, 1995). Uma notável exceção é Thomas (1992), traduzido como Letramento e Oralidade na Grécia Antiga (Odysseus, 2005). 
"literacy", e em virtude da analogia com outros substantivos abstratos formados a partir do sufixo de origem grega -ía, como, por exemplo, monarquia, democracia, confraria, calmaria etc., refira-se de maneira mais clara ao sistema cultural no qual o processo de letramento passou de qualidade acessória à essencial.

Consoante a isso, "literacia" expressaria de maneira mais adequada, a meu ver, o modo como a nossa cultura está organizada, i.e., no uso precípuo que faz da palavra escrita, algo que não fica evidente em "letramento", que, para transmitir a mesma ideia, precisa ser elaborado por meio da perífrase "cultura do letramento". Isso implica, portanto, que "literacia" é mais esquemático ${ }^{10}$ do que "letramento" no que tange ao conjunto de práticas culturais, sociais e individuais que o uso da escritura pressupõe nas sociedades que lhe concedem grande centralidade e, por causa disso, invoca um domínio mais amplo, capaz de induzir um mapeamento metonímico através do qual "literacia" pode ser (re-) interpretado como um traço tão saliente em nossa cultura que é capaz de, por si só, defini-la em contextos específicos ${ }^{11}$.

"Literacia", portanto, ao contrário de "letramento" refere-se inequivocamente a uma cultura na qual o uso da escrita determinou e determina não apenas uma matriz cognitiva que nos é própria mas que é usada também para construir de uma maneira muito particular vários conceitos importantes ligados à dicotomia ORAL x ESCRITO ${ }^{12}$. Essa mesma matriz é, além disso, responsável pela forma como projetamos seus domínios mais prototípicos em culturas de outras sociedades, tanto antigas quanto contemporâneas, na qual o uso da escrita não teve ou não tem um papel tão central, como postulo para a Grécia Antiga ${ }^{13}$, ponto focal deste artigo, onde usarei os dois termos nessas acepções, isto é, "letramento" para o processo, "literacia" para o sistema.

\section{Literatura e Oratura: delimitação conceitual}

Na medida em que o próprio interesse pelas culturas orais é um fenômeno recente, oriundo da percepção de que essas culturas não são, necessariamente, menos sofisticadas do que a nossa sociedade, marcada pela literacia ${ }^{14}$, fica evidente que o conceito de ORALIDADE é enquadrado a partir do domínio do de LITERACIA ${ }^{15}$. Em outras palavras, de acordo com o nosso modelo cognitivo idealizado, LITERACIA é a categoria que inclui ORALIDADE como um dos seus termos marcados ${ }^{16}$, isto é, menos prototípicos. Justamente por essa razão, dispomos de uma palavra para nos referir tanto ao uso artístico da linguagem em sua forma escrita quanto aos seus diferentes corpora, viz., "literatura", mas carecemos de um

9 Vide n. 8, acerca da tradução de literacy por "cultura do letramento" no livro de Olson e Torrance.

10 Termos em itálico representam conceitos dentro da linguagem técnica da Linguística Cognitiva (LC). Acredito que a maioria dos termos aqui empregados sejam autoexplicativos. Contudo, para um leitor interessado, recomendo a consulta ao glossário de termos da Linguística Cognitiva de Evans (2007).

$11 \mathrm{O}$ enunciado "vivemos em um democracia", i.e., "vivemos em uma cultura que se pauta por instituições democráticas", autoriza, do ponto de vista funcional, o uso do enunciado "vivemos em uma literacia", viz., "uma cultura que se pauta pelo uso da palavra escrita".

12 Termos em caixa alta indicam conceitos abstratos dentro da LC.

13 Por conveniência, chamo de "Grécia Antiga" o intervalo entre, aproximadamente, 1200 a 323 AEC.

14 Finnegan (2017 [1977]). Literacia, a partir daqui, sem aspas.

15 Ong (2004)

16 Sobre a lógica da marcação, cf. Battistella (1996) e Waugh (1982), p. 299-318. 
termo satisfatório que defina com precisão aquela produção e corpora de manifestações artísticas orais ${ }^{17}$. Para tanto, é preciso elaborar sobre o termo não-marcado LITERATURA, empregando-o em sua interpretação positiva, menos esquemática, de "literatura oral".

Dessa maneira, em sua forma não-marcada, "literatura" implica automaticamente a palavra escrita (mesmo etimologicamente: > littera, lat. "letra"), impondo-se como uma característica preconcebida para a categorização de obras de arte verbais ${ }^{18}$. Quando se fala, por exemplo, em "literatura brasileira", a poucos ocorrerá de pensar no repente e nas cantorias do nordeste brasileiro, ou na trova e na pajada do sul, ou, ainda, expandindo-se para uma literatura mundial, nas inúmeras manifestações de arte verbal da África ocidental e dos Inuíte do Alasca como membros representativos dessa categoria, a despeito do grau de sofisticação, complexidade artística e ancestralidade dessas formas de arte ${ }^{19}$, para as quais nos vemos até mesmo em dificuldade para encontrar uma denominação satisfatória, tendo sido propostas, entre outras, "épos"20, "vocalizações", "formas de arte puramente orais", etc. Não seria, talvez, conveniente lançar mão de um neologismo como "oratura" ou "oralitura" 21 ? Ao menos com esses últimos poderíamos definir de maneira mais exata o tipo de produção artística que temos em mente, sem que a associássemos (ou ao menos minimizássemos essa associação) ao espaço mental invocado por "literatura" que é, como já vimos, determinado por ideias ligados à literacia em que vivemos. Seria, no entanto, tamanho rigor terminológico realmente necessário? Ao que tudo indica sim, e, por esse motivo, irei adotar o termo "oratura" ao longo desse artigo para me referir a obras de arte verbais conceitual- ou medialmente orais ${ }^{22}$.

17 Ong (2004), p. 10.

18 Goody (1963), p. 78. Ong (2002[1982]), p. 10, analisando a posição de Finnegan (1977), p. 12, coloca a questão de forma bastante clara ao dizer que "But concepts have a way of carrying their etymologies with them forever. The elements out of which a term is originally built usually, and probably always, linger somehow in subsequent meanings, perhaps obscurely but often powerfully and even irreducibly. Writing, moreover, as will be seen later in detail, is a particularly pre-emptive and imperialist activity that tends to assimilate other things to itself even without the aid of etymologies" [grifo meu].

19 Bastaria citar aqui o nome do poeta cego e semianalfabeto Antônio Gonçalves de Silva (1909-2002), que pela doçura de sua poesia, ficou famoso como "Patativa do Assaré", bem como de outros poetas (semi-) analfabetos do sertão nordestino, como Bastião (Bernardo Ferreira), cujo canal no YouTube, Bisaco do Doido (http://www.youtube.com/user/bernardogarapa) conta com mais de 35 mil inscritos e tem despertado a atenção mundial com mais de 14 milhões de visualizações.

20 De acordo com Ong (2004), p. 13, uma sugestão de Northrop Frye em The Anatomy of Critiscism. As outras sugestões também são de Ong, ibid., que manifesta sua esperança de ver o termo "voicings" (vocalizações) difundido nos estudos especializados, embora prefira usar o termo mais tradicional "purely oral art forms" ("formas de arte puramente orais").

21 Uma vez que "oratória" já se encontra empregado para outro uso. "Oralitura" foi cunhado por Ernst Mirville, que, em uma nota a um texto de 1974 do periódico Le Nouvelliste, anunciou a publicação de um artigo seu sobre aquele conceito. O artigo, de fato, apareceu em doze de maio de 1974 no mesmo periódico (LAROCHE, 2009, p. 1-10). "Oratura" é creditado ao linguista e crítico literário Pio Zirimu e a Austin Bukenya, que o teriam cunhado em 1977 no artigo intitulado "Oralcy as a Tool for African Development", lido na Festac de 1977 em Lagos, apud Thiong'o (1998). O termo "oratura" (ing. orature) parece, de fato, ter uma frequência maior nos países anglófonos e está especialmente ligado aos estudos pós-colonialistas da literatura africana. Finnegan 2005 [1992], p. 15 nota que "It avoids the etymological problems of 'oral literature' and is also a positive term in its own right (the parallel to écriture) in the context of "decolonising the mind"". A partir daqui, oratura é o termo que irei usar para a interpretação positiva "literatura oral". Oracia, por outro lado, como contraponto de literacia, dispensando as aspas em ambos os casos. Consequentemente, literatura referir-se-á apenas às artes verbais escritas.

22 Para a distinção entre oralidade medial e conceitual, vide, sobretudo Koch e Österreicher (1986; 1994). 
Esse tipo de limitação da linguagem, que emerge quando tentamos pensar o espaço conceitual delimitado por artes verbais orais, nada mais revela que as limitações do nosso próprio pensamento como indivíduos criados em uma literacia, para os quais é difícil entender ou conceber adequadamente o funcionamento de uma oracia, seja primária ou secundária $^{23}$, o que normalmente fazemos, conscientemente ou não, de uma maneira analógica e, não menos ironicamente, por meio da escrita. Isto acontece, não só porque em nossa cultura "literatura" abarca como categoria superordenada "oratura" (i.e. = literatura oral), mas, sobretudo, porque, uma vez letrados (o que idealmente aconteceria entre os 7-9 anos de idade), habituamo-nos a analisar um sistema primário de comunicação (a fala) por meio de um sistema secundário de modelagem (a escrita), como se este determinasse aquele e não o contrário, como, de fato, ocorre, já que a expressão oral naturalmente precede à escrita ${ }^{24}$ e pode dela prescindir, mas não inversamente, como observa Ong ${ }^{25}$, ao chamar a atenção para o fato de que, das milhares de línguas que já foram ou são faladas, apenas 106 desenvolveram um sistema de escrita e que, das cerca 3000 línguas faladas no mundo hoje, apenas 78 produziram algum tipo de literatura (ONG 2004, p. 7$)^{26}$. Esses números podem nos surpreender apenas se tomarmos a escrita e a literatura tanto como um fenômeno diatópica e diacronicamente homogêneo quanto como o ponto para o qual todas as culturas humanas devem inexoravelmente convergir em sua evolução. Essa, no entanto, é uma concepção enviesada pelo nosso próprio sistema cultural e por noções preconcebidas de "cultura", "evolução", "literatura", etc. Literacias e oracias não apenas diferem em vários aspectos como determinam diferenças igualmente importantes nos hábitos mentais e estruturas conceituais daqueles que nelas participam, e isso se revela nas elaborações metapoéticas ou metalinguísticas desses indivíduos, como alguns dos exemplos citados ao longo desse artigo provavelmente servirão para mostrar.

Numa literacia como a em que vivemos, por exemplo, as palavras têm uma realidade concreta, são entidades discretas perfeitamente isoláveis e adquiriram grande estabilidade ao serem fixadas pela escrita, tornando-se, portanto, recuperáveis e reiteráveis a qualquer momento e com total precisão por meio visão. A dimensão temporal encontra-se abolida na palavra escrita, que foi, finalmente, libertada do eterno presente a que estava condicionada. Em uma oracia, pelo contrário, o próprio conceito de palavra pode ser difuso, instável ou simplesmente não existir, uma vez que o meio de uma vocalização, que é o som, é intangível e fugaz por natureza e, dessa forma, qualquer enunciação apenas se completa no momento mesmo em que deixa de existir. Além do mais, não há fronteiras definíveis entre as palavras dentro de uma mesma enunciação, mas uma cadeia sonora que, associada a um determinado contexto e inúmeros outros recursos comunicativos (gestos, entonação, postura corporal, expressão facial, cenário, coreografia etc.) vão

23 Assim, Thomas (1992) p. 2 seq. Oralidade primária e secundária implicam, respectivamente, culturas sem nenhum tipo de contato ou com apenas um contato marginal com a escrita, os termos são de Ong (2004, p. 10-1), que expressa de modo bastante contundente essa visão tida como extrema por outros estudiosos, segundo a qual "a literate person cannot fully recover a sense of what the word is to purely oral people. In view of this pre-emptiveness of literacy, it appears quite impossible to use the term literature to include oral tradition and performance without subtly but irremediably reducing it somehow to variants of writing" [grifo meu].

24 Zumthor (2010), pp. 11, 142 e passim.

25 Ong (2004), p. 8.

26 Como diz Havelock (1991) "The natural human being is not a writer or a reader but a speaker and a listener. This must be as true of us today as it was seven thousand years ago". 
construindo um sentido ${ }^{27}$. Essas distinções são válidas lato sensu até mesmo se considerarmos culturas liminares, ou mistas, como o foi a Grécia clássica do séc. V AEC.

Se, portanto, no estágio em que nos encontramos em nossa literacia, as palavras são monumentos, em uma cultura oral elas são, ao contrário, eventos ${ }^{28}$. Consequentemente, a palavra em uma oracia define-se tanto por sua impermanência quanto por sua constante renovação a cada enunciação e, por isso mesmo, para os indivíduos que dela fazem parte, é impossível repetir o dito e/ou (re)lembrá-lo, comunicá-lo ou compartilhá-lo de uma maneira "literal", isto é, a partir de um registro que obviamente não existe. Ou melhor, a evocação do dito é, paradoxalmente do ponto de vista de nossa literacia, sempre "literal", no sentido marcado de "fiel" que damos a essa palavra. Isso porque, na ausência de um registro escrito, a última instanciação de um texto é sempre a "original". Daí a repetida assertiva dos guslari estudados por Lord de que seriam capazes de reproduzir uma canção "literalmente" e sem alterações após ouvi-la uma única vez. Deduz-se daí, obviamente, que o conceito "literalmente" tem sentidos diferentes em uma literacia e em uma oracia ${ }^{29}$.

Essas observações aparentemente evidentes acerca da natureza da fala têm implicações profundas para um entendimento adequado de culturas nas quais a escrita ou não existe ou é ainda incipiente ou, ainda, se constitui numa tecnologia dominada por poucos, como se postula ser o caso para a Grécia antiga ${ }^{30}$. Como se poderá constatar ao longo de todo esse artigo, essas implicações foram, durante muito tempo, desconsideradas pela maioria dos estudos produzidos por teóricos operantes a partir de uma literacia na qual a fala naturalmente não tem mais a mesma centralidade. Não são raras, portanto, as tentativas de explicar as oraturas de culturas ágrafas ou semiágrafas como se fossem "textos falados" 31 , aplicando-lhes todas as ferramentas criadas e aperfeiçoadas durante séculos pela crítica literária. Nunca é demais lembrar, no entanto, que, no ocidente, a passagem a uma literacia, se dá apenas a partir de meados do séc. XIX, com a popularização da imprensa e os esforços empregados pelos governos nacionais para expandir o letramento de suas populações ${ }^{32}$.

\section{A Oratura Grega Arcaica: um olhar ampliado}

No início da década de sessenta, abordagens cognitivas às ciências humanas produziram uma série de experimentos reveladores acerca da maneira como construímos significado a partir de nossa interação com o mundo e, especialmente, como a introdução de novas tecnologias afeta a maneira como se estruturam os nossos processos mentais ${ }^{33}$. Mais especificamente, nos estudos sobre a oralidade, foram publicados, entre os anos de

27 “A voz não traz a linguagem: a linguagem nela transita, sem deixar traço. (...) A voz se diz enquanto diz; em si, ela é pura exigência”, Zumthor (2010), p. 11.

28 Ong (2004), p. 31.

29 De especial relevância aqui são os testemunhos de Sulejman Makić e Đemo Zogić, em Lord (1971 [1969]), pp. 26-9 e 99-123.

30 Thomas (1992), p. 3 seq.

31 Sobre isso $c f$. Finnegan 2005 [1992], p. 15.

32 Vide Carl. F. Kaestle, History of Litercy and Readers, in Kintgen et al. (1988) pp. 95-126. Sobre a revolução da imprensa e a sua influência no aumento da literacia, $c f$. Eisenstein (1980).

33 Isso talvez tenha ficado agora mais evidente do que nunca quando presenciamos uma outra mudança de paradigma cognitivo causado pelas mídias digitais e o smart phone. 
1962 e 1963, três trabalhos que, de maneira independente, chegaram a essa conclusão, aqueles de M. McLuhan, The Gutemberg Galaxy, Jack Goody e Ian Watt, The Consequences of Literacy e, no âmbito dos estudos clássicos, o livro de Eric Havelock, Preface to Plato $^{34}$. Ainda, nas décadas de 80 e 90, as contribuições feitas pela Linguística Cognitiva, sobretudo a partir do trabalho de Lakoff-Johnson, Langacker e Fillmore ${ }^{35}$ ajudaram a solidificar as premissas desenvolvidas por aqueles pesquisadores. Finalmente, a ideia de que os construtos (e não as capacidades) mentais dos indivíduos de uma oracia e de uma literacia diferem consideravelmente ${ }^{36}$ iria encontrar sua versão mais explícita no influente, ainda que bastante polêmico, livro de Walter J. Ong, Orality and Literacy: The Technologizing of the Word $^{37}$.

Hoje sabemos, sobretudo pelos experimentos levados a cabo por linguistas e psicólogos trabalhando com um abordagem cognitiva da percepção humana e dos processos de formação da linguagem, que nós, ao mesmo tempo em que partilhamos de categorias comuns por meio dos quais organizamos nossa conceitualização e interpretação do mundo, sobretudo no que diz respeito a domínios mais básicos de orientação espaço-temporal, também possuímos uma grande variedade de modelos cognitivos idealizados que são culturalmente motivados. O princípio da ancoragem corporal da mente ("embodiment principle") e dos conseguintes processos metafóricos a que o pensamento cotidiano está sujeito é, aliás, um dos preceitos básicos das Ciências Cognitivas, como desenvolvidas a partir dos trabalhos de Lakoff-Johnson, Langacker, Fillmore e Fauconnier ${ }^{38}$. É natural, portanto, supor que sociedades que se estruturam de formas diferentes devam otimizar seus processos mentais diferentemente dos nossos, a fim de melhor lidar com seu ambiente e problemas, que lhes são próprios.

No que tange às sociedades orais, Ong (2002 [1982]) propõe, por exemplo, que o discurso tende a se manifestar por meio de uma organização aditiva ou paratática ao invés de subordinativa ou taxonômica, com predominância da adjetivação sobre a predicação e da redundância sobre a síntese. Há, além disso, um viés em favor do conservadorismo em detrimento da inovação e da corporificação por meio de uma homeostase que subordina o passado ao presente, de forma que aquele esteja sempre em concordância com este ${ }^{39}$. $\mathrm{O}$ pensamento pragmático, mediado por uma lógica agonística, tende a se sobrepor à abstração, o que favorece a empatia e o comunalismo sobre a objetividade e o individualismo. Como consequência, o raciocínio tende a ser situacional, mais do que abstrato, e a autoavaliação é feita a partir da avaliação do grupo ${ }^{40}$.

34 Respectivamente McLuhan (1962), Goody e Watt (1963), Havelock (1963).

35 Lakoff e Johson (1980; 1987; 1999); Langacker (1999; 1999; 2008); Fillmore (2006); Fauconnier (1985).

36 Algo muito bem colocado por Havelock (1991), p. 66, que vê as capacidades de diferenciação e contextualização como essenciais na caracterização de culturas, respectivamente, literatas e orais. Diz ele, no entanto, "Cross-cultural differences in thought concern habits of thinking, not capacities of thought [grifo meu]. All humans are capable of and do practice both differentiated thinking and its opposite, integrated thinking, as well as both contextualized and decontextualized thought. However different cultures make some of these thought patterns fluent and automatic, whereas the opposite patterns remain unusual cumbersome".

37 Ong (2002 [1982]). Interessante também, nesse sentido, o que diz Havelock (1991), p. 33: "In an oral culture, restriction of words to sound determines not only modes of expression, but also thought processes",

38 Vide n. 35 .

39 Cf. Goody (1963), p. 310, "One of the most important results of this homeostatic tendency is that the individual has little perception of the past except in terms of the present."

40 Sobre isso, é importante considerar a distinção que Dodds (1966) faz entre "culturas de culpa", como a nossa, e "culturas de vergonha", como a Grécia antiga, e refletir se a última categoria não seria mais comum em oracias. 
Todas essas características, em maior ou menor grau, podem ser encontradas exemplificadas na oratura da Grécia antiga até, pelo menos, o período clássico e elas são conspícuas e universalmente reconhecidas na épica heroica e didática de Homero e Hesíodo. $\mathrm{O}$ fato de as evidências etnológicas listadas por Ong virem sobretudo de sociedades contemporâneas não deve, portanto, nos levar a pensar que suas conclusões sejam menos válidas para a Grécia antiga. Ao contrário, como muito bem coloca Finnegan:

\begin{abstract}
Nesta área, como em outras, uma perspectiva comparatista pode ser esclarecedora. Na literatura pode-se aprender muito, por exemplo, ao considerar Homero à luz das descobertas da poesia épica iugoslava atual ou daquelas feitas sobre poetas esquimós ou gilberteses, ou sobre os cantores de blues modernos. De modo similar, alguns aspectos da poesia podem provar não ser peculiares a, digamos, Homero ou Piuvkaq ou 'Left Wing Gordon', ou mesmo (como sugerido em algum trabalho linguístico) à 'cultura indo-europeia', mas praticado e executado em muitas áreas do mundo. Uma perspectiva comparatista pode levar a uma conscientização acerca da complexidade e da diversidade das formas através da história e da cultura humanas, bem como lançar dúvidas sobre algumas dicotomias usadas por cientistas sociais no passado - aquela, por exemplo, entre sociedades 'civilizadas' contra 'primitivas' e 'simples'; ou, ainda, uma Gesellschaft oposta a uma Gemeinshaft; ou cultura 'moderna' contra 'tradicional'.,"41
\end{abstract}

Sob o crivo dos nossos próprios estereótipos culturais, pode parecer, no entanto, que sociedades orais, como as citadas no trecho acima, por não possuírem uma tradição escrita (não raramente identificada com a própria "cultura"), dificilmente poderiam alcançar uma sofisticação intelectual que lhes permitisse produzir aquilo que estamos acostumados a identificar com "poesia", ou seja, uma forma altamente estilizada de linguagem que pressupõe um refinamento e um trabalho árduo com a palavra escrita. Por outro lado, muitos estariam prontos a admitir que diversas sociedades, ou mesmo parcelas de nossa própria sociedade, apresentam manifestações orais que podem ser caracterizadas como "poesia popular", onde o termo "popular" serve justamente para marcar o caráter menor desse tipo de produção cultural. Por meio do viés da nossa literacia, a oratura é duplamente estigmatizada, isto é, conceitualizada não apenas como interpretação negativa do termo não-marcado, "literatura" (oratura = literatura não escrita) mas também, ou por isso mesmo, deficiente em relação a essa e, consequentemente, inferior.

Não deixa de ser irônico, portanto, que a maior revolução na pesquisa sobre literatura oral, especificamente de poesia, tenha se desenvolvido a partir do estudo da dicção daquele poeta tido como o "pai da literatura" no ocidente e, durante muitos séculos, considerado a epítome do refinamento literário, Homero.

Foi sobretudo a partir dos trabalhos de Milman Parry ${ }^{42}$ com os épicos homéricos que se pode entender a verdadeira natureza da técnica composicional da Ilíada e da Odisseia,

41 Finnegan (2017[1977]), p. 3, todas as traduções são minhas, a menos que indicado em contrário.

42 Principalmente em The Traditional Epithet in Homer (TE), Homeric Formulae and Homeric Metre (FM) e Studies in the Epic Technique of Oral Verse Making (HS) I e II, todos reunidos em Parry (1971). É preciso notar, no entanto, que a teoria de Parry não era completamente sem precedentes. Antes dele (e provavelmente sem o seu conhecimento) J. E. Ellendt e H. Düntzer já haviam notado a dependência entre a escolha de palavras e o metro hexamétrico, Van Gennep já havia identificado o uso de fórmulas na poesia oral de outras culturas e, sobretudo, M. Jousse já havia traçado uma distinção bastante clara entre composição oral e escrita, chegando a formular o importante conceito de culturas "verbomotoras". 
o que revolucionou completamente os estudos acerca da oralidade, a ponto de seu trabalho ter se tornado quase que uma espécie de "teoria universal" da poesia oral, o que atesta a onipresente citação de seu nome em trabalhos sobre o tema.

Não me deterei aqui sobre os detalhes de suas descobertas, basta dizer que a principal conclusão a que Parry chega é que os poemas homéricos foram compostos em um estilo que pressupõe uma técnica oral de composição-em-performance que faz uso de uma dicção tradicional construída a partir de um sistema de fórmulas organizado a partir de um princípio de extensão (length principle) e economia (thrift principle) do hexâmetro homérico ${ }^{43}$. Mais tarde, Alfred B. Lord ${ }^{44}$, em um trabalho de campo com os guslari iugoslavos, iria comprovar empiricamente as principais teses de seu professor ao coligir e analisar centenas de canções compostas oralmente que atestam os princípios composicionais propostos por Parry.

Embora o trabalho de Parry e Lord não tenha sido recebido com aclamação universal, mesmo modernamente, não demorou muito para que a sua influência começasse a ser sentida, sobretudo fora da filologia clássica, entre os interessados no estudo etnográfico das sociedades e culturas orais contemporâneas. Em pouco tempo, porém, sua teoria de uma dicção tradicional regida pelo uso de fórmulas tornou-se a pedra fundamental sobre a qual uma teoria da oralidade de qualquer tipo de texto, do Beowulf aos salmos bíblicos ${ }^{45}$, deveria estar embasada. Na verdade, o próprio Parry aplicou as conclusões a que chegara com Homero a autores da literatura grega ${ }^{46}$ operantes em outras tradições, como a lírica e o drama, procurando mostrar que toda a poesia pós-homérica já não era mais oral, uma vez que dela estava ausente a "esquematização", isto é, a combinação de fórmulas governadas pelo tema e pelos princípios de extensão e economia, que ele identificava como marcas inequívocas da oralidade.

A empolgação com as descobertas de Parry, levou Lord a manifestar, pela primeira vez, a ambição de definir uma poética da oralidade baseada na interpretação estrita das teorias de seu mestre, ou, como diz, “ obter evidências a partir das quais possam ser derivadas uma série de princípios gerais aplicáveis a todas as poesias orais. (...) Um método aqui se impõe que consiste em definir as características do estilo oral"47. Ainda hoje, "literatura" oral - sobretudo poesia oral -, e "estilo formular" parecem se implicar mutuamente em muitos estudos. Há, no entanto, uma série de problemas, tanto metodológicos quanto de escopo, que impedem que tenhamos essa relação como inequívoca, alguns deles levantados por R. Finnegan em seu livro Oral Poetry ${ }^{48}$.

Em primeiro lugar, segundo essa autora, é preciso decidir o quão formular um determinado estilo precisa ser para que possamos caracterizá-lo como oral. Para Lord é possível utilizar a densidade de expressões formulares (entre 50\% a 60\%) e de fórmulas propriamente ditas (entre $10 \%$ e $25 \%$ ) para se decidir a favor de, ou contra, o caráter oral de qualquer composição ${ }^{49}$. No entanto, como argumenta Finnegan, textos escritos também podem apresentar altos índices de estruturas formulares e fórmulas, como é o caso do

43 Parry (1971), p. 269-70.

44 Lord (1971 [1969]).

45 Vide, por exemplo, R. Culley, Oral Formulaic Language in the Biblical Psalms, 1967.

46 Parry (1971), p. 279 seq.

47 Parry (1971), p. 4.

48 Finnegan (2017 [1977]), p. 69 seq.

49 Lord (1971 [1969]), p. 30 et seq. 
Beowulf, da Canção de Roland e de outros documentos medievais. De uma maneira ainda mais significativa, isso acontece também em tradições ainda vivas de poesia oral, como entre os Xossa e os Zulu, em que poemas formulares podem ser produzidos tanto oralmente e de improviso (assim casando adequadamente com a visão de Parry-Lord), mas também podem ser simplesmente escritos, o que coloca em risco a credibilidade do uso de um critério baseado na forma para decidir quanto ao caráter oral ou não de qualquer texto. Além disso, a própria definição de "fórmula", da qual essas estatísticas dependem seria, segundo Finnegan, pouco clara para permitir generalizações no tocante à determinação de um estilo como oral ou não ${ }^{50}$.

A poesia hexamétrica apresenta um enorme grau de esquematização. Mas se essa esquematização, como argumenta Finnegan com razão, não é a característica essencial da obra oral, quais então seriam? Por quais critérios poderíamos nos guiar em nosso estudo da oratura do passado, da qual nos restam apenas os textos? A base mais segura, como acredito, não está apenas na forma, mas no conteúdo do discurso, que evoluiu, como já disse, para representar de maneira optimizada uma estrutura conceitual típica de cada sociedade e, dessa forma, textos produzidos em oracias devem apresentar características não apenas distintivas desses sistemas, mas igualmente diversos daqueles produzidos em uma literacia. Além dos critérios estabelecidos por Ong, citados logo acima, podemos ainda, apelar à linguística em busca de outras pistas que revelem a estrutura conceitual-cognitiva de textos orais e escritos.

A coexistência entre oralidade e escritura aludida por Finnegam entre os Xossa e os Zulu, e presente também entre os guslari estudados por Parry e Lord, traz à baila a importante distinção já mencionada feita por Koch e Österreicher (1994) entre a natureza medial e conceitual de um texto. Assim, por exemplo, um discurso, uma canção, um roteiro de cinema, muito embora escritos, foram concebidos para ser falados, e são, portanto, conceitualmente orais. Por outro lado, um artigo científico foi concebido para ser transmitido através da escrita e, muito embora ele possa ser lido em voz alta, num congresso, por exemplo, permanece conceitualmente escrito. As estratégias comunicativas empregadas por textos conceitualmente orais ou escritos são completamente diferentes: qualquer um que já tenha tido que suportar a leitura de um artigo em uma conferência não irá duvidar da inadequação da forma ao propósito, que, pela incapacidade de manter a atenção do leitor, mais valor teria como soporífico. Por outro lado, dificilmente uma conferência irá ser aceita para publicação em um jornal acadêmico sem sofrer uma verdadeira tradução intersemiótica.

Essa distinção entre oralidade medial e conceitual foi explorada por Bakker (1997) para tentar explicar a linguagem homérica como uma estilização progressiva de características naturais da fala (speech), bem como para estudá-la a partir de um ponto de vista que levasse em consideração a optimização cognitiva do texto num contexto de comunicação oral. Essa distinção é importante, porque ela remove uma série de problemas e mal entendidos acerca de se entender o sentido mais fundamental em que a linguagem homérica pode ser dita oral. Além disso, ela abre caminho para considerarmos o restante da literatura arcaica e clássica a partir de critérios mais amplos que aqueles delimitados pelos princípios estabelecidos por Parry e Lord para a épica grega, o que nos habilitaria a considerar a possibilidade de que outros poetas também compunham a partir de uma pa-

50 Finnegan (2017 [1977]), p. 71 seq. Para uma crítica semelhante, v. Sale (2001), p. 56. 
radigma ditado pelas regras de uma oracia, mesmo após o advento da escrita. Ademais, o problema de quando teria surgido e de quão difundida estaria a escrita até o fim do período clássico, pouco importaria para a determinação do estatuto de um texto, se oral ou não.

Outra dimensão importante, apontada por Zumthor ${ }^{51}$, é aquela entre documento e monumento. Segundo esse autor, a poesia privilegia, no nível poético (que se define por seu caráter secundário, i.e., intencional e resultante de um trabalho) a estrutura modal em detrimento da textual. De seu turno, a estrutura modal é, por definição, de ordem " gráfica (tendendo para o desenho) quando se trata da escrita; vocal (tendendo para o canto), tratando-se de oralidade" 52 e, dessa forma

A parte das estruturas textual e modal na constituição do monumento difere sensivelmente na poesia escrita e na oral. O textual domina o escrito; o modal, as artes da voz. Em último caso, um monumento oral seria concebível inteiramente modalizado, mas nunca [inteiramente] textualizado. Entretanto, duvido já ter encontrado um exemplo desse tipo. ${ }^{53}$

A compreensão de Zumthor acerca das qualidades de uma composição oral, ainda que em grande medida expressa de uma maneira intuitiva (advinda, aliás, da enorme familiaridade do autor com as mais diferentes formas de oraturas), é de grande valia e se aproxima muito daquela já exposta no jargão estruturalista de Jakobson quando este nos diz que a poesia "projeta o princípio da equivalência do eixo da seleção sobre o eixo da combinação" 54 ou, se quisermos usar a nomenclatura desenvolvida por Hjelmslev (1961), efetua a projeção do plano da expressão sobre o plano do conteúdo, uma formulação que particularmente prefiro.

Pensando, dessa forma, em textos compostos ou escritos para a performance, isto é, conceitualmente orais, podemos tentar reconhecer marcas que os distingam de textos conceitualmente escritos. O poema em performance aponta, por exemplo, sempre e necessariamente para a frente, sem que qualquer tipo de retorno ou repetição seja possível. As relações sintagmáticas e subordinativas aí se apresentam naturalmente enfraquecidas, quando não de todo ausentes, ao passo que os processos dêicticos dão predominância à catáfora ou empregam recursos cognitivos que privilegiam à imagética em detrimento da gramática ${ }^{55}$ para a construção do sentido. Tais características encontramos, por exemplo, num poeta sofisticado como Píndaro, cujo estudo sempre foi marcado pela crux do problema da unidade ${ }^{56}$ e cuja sintaxe, por ser sentida como peculiar a partir de uma paradigma literário, já foi objeto de muita tinta ${ }^{57}$.

Num poema oral, contudo, nem tudo precisa ser explicado. Na verdade, normalmente

51 Zumthor (2010), p. 39 seq.

52 Idem, p. 40

53 Idem, p. 50.

54 Jakobson (1987), p. 70.

55 Zumthor (2010), p. 41, “(...) a mensagem transmitida pela boca é compreendida na medida em que se desenvolve concreta e progressivamente" e "a estruturação poética, em regime de oralidade, opera menos com a ajuda de procedimentos de gramaticalização (como o faz, de maneira quase exclusiva, a poesia escrita) do que por meio de uma dramatização do discurso. A norma se define menos em termos de linguística do que de sociologia. Porém (por este mesmo motivo), a poesia oral geralmente comporta mais e mais complexas regras do que a escrita: nas sociedades de forte predominância oral, ela constitui, muitas vezes, uma arte muito mais elaborada do que a maior parte dos produtos de nossa escrita" [grifo meu].

56 Young (1970).

57 Como o extenso estudo de Hummel (1993), por exemplo. 
sequer existe uma expectativa ou pressão para que eventuais rupturas semânticas ou pequenas incongruências, ou até mesmo eventuais contradições, sejam resolvidas. O desejo de análise é característico da mente literária, mas ele carece de oportunidade no tempo de urgência imposto pela performance ${ }^{58}$, onde o público precisa ser capaz de compensar pelas brechas que esse tipo de comunicação implica, ou, para usar o feliz termo de Zumthor $^{59}$, que ele seja capaz de preencher a vacância semântica do discurso, que tem seu espaço "espremido, mas sobrecarregado de valores alusivos" que "deliciosamente" obrigam o ouvinte à interpretação. Isto, obviamente, se dá a partir do contexto compartilhado pelo poeta e seu público, mas esse contexto nem sempre é recuperável pelo registro escrito de uma performance, posto que suas marcas podem ser mais elusivas e são, por necessidade, dependentes do texto preservado apenas. Daí, de acordo com aquele autor

\begin{abstract}
“(...) a impressão que às vezes tem o observador de que o aspecto verbal da obra oral é menos cuidado que seu aspecto prosódico ou musical: ponto de vista de pessoas de escrita. Os poetas interrogados sobre sua arte, nas culturas com predominância oral, descrevem-na em termos que evocam um domínio da manifestação discursiva, produtora de significações inconcebíveis fora das formas que ela realiza. $O$ "sentido" aqui é direção, vetor, mais que culminância [grifo meu]. O grande Orpingalik, Inuíte de Netsilik, dizia a Rasmussen: "Meu ser é canto"; os guslar iugoslavos de Lord eram incapazes de distinguir entre as noções de "palavra", "enunciado" e "verso", confundindo-as quase na ideia de som e de voz. Da mesma maneira, o contador navajo estudado por Barre-Toelken só falava de suas próprias narrativas em termos de língua, não de narração." ${ }^{60}$
\end{abstract}

A estruturação da obra oral em forma de nebulosa galáctica, um beau désordre ${ }^{61}$, é típica da poesia oral. A alta entropia do discurso poético pode ser, contudo, enganosa à mente quirógrafa. Isto porque, sob a superfície que turbilhona, se escondem forças poderosas e complexas que agem em conjunto para manter a coesão do discurso e para agregá-lo em torno de um núcleo comum, frequentemente apenas discernível quando expresso na tridimensionalidade do som, do cenário, dos gestos etc. Em meio ao movimento aparentemente desordenado de expansão da voz poética, há um vetor, como o quer Zumthor na passagem citada acima, que guia e paulatinamente dá forma ao sentido, que "emerge de um não lugar, de um não dito, no espírito do ouvinte, a cada performance mutável, aqui e agora".

Do "não-dito", porque é, por outro lado, na tessitura e na própria malha do plano da forma (e portanto, a partir de elementos não-verbais) da obra poética enquanto ato que se ocultam as marcas características dessa "linda linguagem" capaz de construir significados por meio de elementos tanto detectáveis no texto (ou na canção que reste como registro), como o ritmo, a assonância, o jogo de eco, a repetição, os homoioteleutoi, as figuras so-

58 Cf. Zumthor (2010, p. 139), “O ouvinte segue o fio, nenhum retorno é possível: a mensagem deve atingir seu objetivo (seja qual for o efeito desejado) de imediato. No quadro traçado por tais limitações, a língua, mais que na liberdade da escrita e qualquer que seja a visada que oriente seu emprego, tende ao imediatismo, a uma transparência, menos do sentido do que de seu ser próprio de linguagem, fora de toda ordenação escriptível".

59 Zumthor (2010), p. 147 e passim.

60 Zumthor, (2010), p. 140.

61 Como Boileau (1815) caracteriza, aliás, a poesia de Píndaro: "Son style impétueux souvent marche au hasarde | Chez elle un beau désordre est un effet de l'art". 
noras, a paronomásia quanto (frequentemente indetectáveis no texto escrito) a melodia, o cenário, a indumentária, os movimentos associados à dança e à mimese. A presença desses elementos que pedem pela voz deve sempre nos pôr em alerta para a função original de uma composição, da qual eles se constituem indícios valiosos.

Retornando à questão da grande influência que a teoria parriana teve sobre os estudos da oralidade (e que, como vimos, causa um grande desconforto em teóricos conscienciosos como Finnegan), percebemos que a ideia de que a estrutura formular é absolutamente essencial para a memorização de longas canções e, portanto, indissociável de qualquer tipo de poesia oral, tende a minimizar a importância dos elementos da microforma poética, reduzindo a fórmula a um mero expediente mnemônico que só faz sentido se raciocinarmos a partir do texto escrito.

Tanto Lord ${ }^{62}$ quanto Parry ${ }^{63}$ foram bastante explícitos em dizer que a fórmula não é o único elemento necessário à memorização do texto, simplesmente porque a memorização pura e simples não teria nenhum papel na formação de um cantor de contos. O bardo homérico ou iugoslavo não memoriza as fórmulas, ele as absorvia da mesma forma que uma criança absorve a gramática de sua própria língua e, portanto, para ele, elas surgiam do inconsciente da mesma maneira que a fala, no discurso cotidiano. Utilizando-nos de uma analogia, poderíamos dizer que propor que os cantores épicos precisariam decorar suas fórmulas a fim de ser capazes de improvisar em performance é tão absurdo quanto pensar que alguém precise decorar regras de gramática ou expressões idiomáticas para, conscientemente evocando-as no ato da fala, ser capaz de falar um outro idioma. É justamente pela interiorização dessas regras e expressões formulares que se atinge a proficiência em uma determinada língua.

O fato é que o modelo épico de composição oral não pode ser visto como capaz de abarcar todas as formas de oratura que, como nos alerta Finnegan, são variadas e se utilizam dos mais diferentes expedientes. Dessa forma, o modelo de composição-em-performance, típico do poeta épico grego e dos guslari, privilegia a dicção formular justamente porque essa o liberta do jugo da memória e da reflexão criativa em uma arte que prima pela rapidez e pela celeridade, testando a capacidade do poeta de manter um fluxo narrativo constante. Este sistema surgiu constrangido pela própria natureza da sua ocasião de performance, que demanda agilidade de composição. Uma das principais características do poeta grego (e indo-europeu) que opera nesta tradição é justamente a de ver a si mesmo como uma espécie de ventríloquo das Musas, que tanto colocam em seu peito as palavras das canções quanto o impelem a cantá-las ${ }^{64}$.

A performance é, no entanto, apenas um dos determinantes numa tradição de poesia oral, afinal de contas, qualquer poesia pode ser oral de acordo com pelo menos cinco operações $^{65}$ : (1) produção, (2) transmissão, (3) recepção, (4) conservação, (5) repetição. É a partir desses diferentes pontos focais que se pode começar a entender melhor os pro-

62 Lord (1971[1969]), p. 35-6.

63 "Yet no graver mistake could be made than to think the art of the singer calls only for memory", Parry (1971), p. 335.

$64 C f$. a fala de Fêmio na Odisseia (22.347-8), que lembra a definição de Orpingalik, citada mais abaixo:

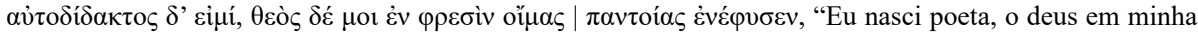
mente veredas [de canções] | de todo tipo implantou”. Sobre isso, vide Brandão (2015), p. 29-47 e o diálogo Íon, de Platão.

65 Zumthor (2010), p. 32. 
cessos distintos que operam em diferentes tradições. Essa segmentação da práxis poética, ademais, permite definir uma linha clara entre transmissão oral, que diz respeito às operações (2) e (3), e tradição oral, que se refere aos processos (3), (4) e (5) ${ }^{66}$. Fica evidente que, nas culturas de oralidade primária, o item (4) existirá de maneira imaterial, apenas na memória coletiva da cultura e determinará, ainda, o horizonte de expectativas do público dessa cultura. Na tradição épica, por exemplo, (1), (2) e (3) são simultâneos, enquanto (4) e (5) ocupam uma dimensão temporal distinta.

Existiriam culturas em que o processo de produção, ainda que oral, poderia estar dissociado temporalmente do de transmissão e recepção? Ou seja, existiriam culturas para as quais poderíamos postular uma tradição de composição oral que estivesse dissociada da composição-em-performance típica do modelo épico e para as quais, portanto, a esquematização da linguagem tivesse um caráter secundário, se algum? De acordo com a evidência etnográfica, a resposta é afirmativa. Como nos informa Finnegan:

Na Somália, no Chifre da África, a poesia oral é uma arte extremamente desenvolvida. (...) A composição poética é uma arte muito valorizada e discutida entre os somalis, que já foram descritos como "uma nação de bardos", e um poeta admirado pode se tornar vastamente conhecido. Um poema somali sempre desperta interesse e discussão e atrai críticas se é considerado medíocre. Sabendo disso, "os poetas somalis raramente executam seu trabalho até que a composição tenha sido finalizada em privado" e "dispendem muitas horas, as vezes mesmo dias compondo suas obras" antes de executá-las (Andrzejewski e Lewis, 1964, p. 45). As composições de um poeta, além disso, tornam-se sua propriedade, sob o seu próprio nome e outro poeta que as recita tem que reconhecer de quem ele as aprendeu. Um bom poeta tem uma trupe de admiradores, alguns dos quais aprendem seus poemas de cor e os recitam. Outros ouvem esses recitais e memorizam os poemas que consideram suficientemente belos e importantes. Andrzejewski e Lewis demonstram que é de fato a memorização mais do que a composição simultânea/em performance que tem lugar aqui. ${ }^{67}$

Nesse exemplo aduzido por Finnegan, que se alinha, em muitos aspectos, com o que sabemos acerca do contexto de composição e performance da lírica grega arcaica, todas as operações descritas nos itens acima se dão de modo independente. Mais importante ainda, há uma brecha temporal entre (1), composição, e (2) e (3), transmissão e recepção. Além disso, há uma série de características nessa tradição de poesia somali que chama a atenção pela forma como se opõe à noção parriana de oralidade. Em primeiro lugar, a composição tem lugar em um momento anterior à performance, sem qualquer tipo de ajuda ou suporte da escrita e, portanto, a composição dos poemas é oral em seu mais estrito senso. Depois, é significativo o papel imprescindível da memória na estabilização de uma versão final que deverá ser apresentada ao vivo e, de novo, na fixação, pelos ouvintes, dessa versão em seus mais ínfimos detalhes, uma vez que há aí bem desenvolvidos tanto um conceito de "autoria" quanto o de uma versão "canônica", a partir das quais os desvios são sentidos como marcados.

A capacidade do poeta, ademais, em compor poemas longos e complexos sem qualquer tipo de suporte da escrita, ou utilizando-a apenas como um aide-mémoire, precisa ser bastante salientada, porque, normalmente, a complexidade está associada em nossa 
literacia à escrita e, não raro, é usada como argumento a priori para descartar a possibilidade de um poema ser oral. Sofisticação e complexidade, no entanto, além de não serem empecilhos à poesia oral, constituem-se, na verdade, em uma de suas principais características. Mais um vez, o exemplo somali pode ser revelador:

Um poema passa de boca em boca. Entre um jovem somali que escuta hoje um poema composto há cinquenta anos atrás, a cinco milhas de distância e sua primeira audiência, há uma longa cadeia de recitadores que o passaram de um ao outro. É apenas natural que neste processo de transmissão alguma distorção ocorra, mas a comparação de diferentes versões do mesmo poema normalmente demonstra um surpreendente e alto grau de fidelidade ao original. Isso se deve, em grande medida à rigidez formal da poesia somali: se uma palavra for substituída por outra, por exemplo, ela ainda assim deve obedecer às regras de aliteração, assim limitando consideravelmente o número de possíveis mudanças. A forma geral do poema, além disso, inibe a omissão ou a transposição de linhas

Outro fator também tem um papel importante: a audiência que escuta o poema logo detectaria qualquer desvio grosseiro do estilo de um poeta particular; além do mais, na audiência, frequentemente há pessoas que já sabem de cor um poema em particular, tendo-o ouvido de uma outra fonte. Disputas acirradas às vezes acontecem entre um recitador e sua audiência no que concerne à pureza de sua versão. Pode mesmo acontecer de a autoria de um poema ser questionada por uma audiência, que atentamente escuta as frases introdutórias na qual o recitador do poema nomeia o poeta e, se ele está morto, diz um prece por sua alma. ${ }^{68}$

Os recursos disponibilizados, portanto, pela microforma poética têm, como dizíamos anteriormente, uma importância capital na estabilização da oratura de culturas orais primárias ou secundárias. Exemplos semelhantes poderiam ser aduzidos em profusão, como no caso da literatura védica, em que textos milenares como o Rgveda foram transmitidos de maneira completamente oral por séculos, não só mantendo absoluta fidelidade ao texto mas igualmente à pronúncia de uma forma linguística que desapareceu muito antes de Homero ter nascido no ocidente. Ou, ainda, como é o caso da poesia escáldica nórdico-islandesa, dos panegíricos ruandeses e sul-africanos ou, por fim, da poesia coral grega, seja lírica ou trágica. De fato, ficamos sabendo por Plutarco ${ }^{69}$, como os prisioneiros atenienses em Siracusa conseguiram se salvar cantando para seus captores partes das canções das peças de Eurípides que haviam aprendido de cor. O paralelo com a transmissão dos poemas somalis não pode ser desprezado:

A maioria dos atenienses morreu nas pedreiras de doença ou da dura rotina. (...) Alguns salvaram-se graças a Eurípides, pois parece que os gregos na Sicília, mais do que todos os outros gregos do exterior, sentiam muita falta da música de Eurípides e cada pequena amostra ou migalha que obtinham dos que chegavam trazendo-as, aprendiam de cor com muito prazer e compartilhavam entre si. Diz-se que muitos dos que se salvaram, ao voltarem para casa, abraçavam Eurípides com muita afeição e lhe contavam, uns, como, enquanto escravos, haviam ganhado a liberdade ao ensinar [aos seus mestres] tudo o que lembravam de seus poemas; outros, que, perdidos depois da batalha, haviam trocado comida e bebida pelos versos que cantavam [grifo meu].

68 Andrzejewski (1964), p. 45-6.

69 Plu. Nic. 29.2-3. 
Rosalind Thomas (2012), seguindo a tradição comparatista preconizada por Finnegan, vê, no que chama de "literaturas performativas" da África, um paralelo etnológico interessantíssimo para entender a complexidade e a dificuldade acordadas a um poeta como Píndaro desde a Antiguidade ${ }^{70}$ sem ter que postular a escrita como meio conceitual de composição. Suas observações são importantes porque muitos helenistas assumem, tacitamente ou não, que, devido à complexidade dos textos dos epinícios, isto é, canções para ser cantadas na ocasião de uma vitória atlética, eles nem poderiam ter sido compostos oralmente nem teriam sido preservados, caso dependessem de uma transmissão puramente oral para tanto ${ }^{71}$. Thomas (2012), no entanto, argumenta que é precisamente a complexidade dessas odes que as monumentaliza e as torna memoráveis:

Quando pensamos acerca de literatura performatizada, ouvida ou lida, normalmente assumimos que o que é ouvido deve ser imediatamente claro, lúcido e compreensível à audiência, e que, se é complexo, seu valor como literatura depende de estudo e releitura. O estilo denso de Tucídides é, dessa forma, tido como pensado para a leitura privada. Doutra forma, poder-se-ia também refletir sobre a oratória ateniense deliberativa, que precisava persuadir sua audiência democrática; ou sobre alguns debates acerca da oralidade de Homero (...). Ainda que ninguém queira negar que uma literatura complexa sempre irá recompensar estudo prolongado e releitura, deveríamos parar para pensar acerca da suposição de que alta complexidade por si mesma faz com que algo seja inadequado à performance.

Pode ser que a literatura performática que existe num contexto virtualmente destituído de escrita poder ter uma maior necessidade de algum tipo de densidade, de modo a tornar a performance mais memorável. (THOMAS, 2012, p. 229)

Assim como a poesia formular descrita por Parry não implicava um automatismo por parte do aedo, também o recurso à memorização de longos poemas, auxiliada e, em grande medida, moldada pelas particularidades e a esquematização da microforma não importa em uma ideia de recepção passiva entre os membros de uma tradição. O poeta não opera a partir de partes pré-fabricadas de seu poema. Como acabamos de ressaltar, antes da execução de qualquer obra, há um processo de composição longo e meticuloso no qual o poeta precisa se engajar ativamente com as ferramentas e os materiais que a tradição lhe oferece. A linguagem poética desses poetas é, da mesma forma que aquela dos aedos homéricos ou dos guslari iugoslavos, aprendida oralmente durante um longo processo de iniciação. Para o poeta somali ou para o grego, que operam em uma tradição lírica, uma grande parte do processo de composição poética permanece incompreensível,

70 Para uma visão que relativiza essa dificuldade e a coloca em sua devida perspectiva, $v$. sobretudo Most (1985) e Hamilton (2003).

71 As aporias de Irigoin (1952), p. 5-6, nesse sentido, revelam como a escrita é pressuposta a priori em uma discussão sobre a gênese dos epinícios : "Une ode chorale, écrite dans des conditions déterminées (...)" ou, logo em seguida: "Avant le manuscrit original, autographe du poète ou copie de ses notes établie par um homme de métier, comment s'élabore le poème? Ces vers lyriques inégaux, souvent fort longs, qui reviennent régulièrement dans les éléments strophiques de l'ode, comment le poète les compose-t-il ? A-t-il un schéma directeur sous les yeux, ou se fie-t-il uniquement à sa mémoire ? Voilà déjà une question qui reste sans réponse". Mas: "Une fois le poème mis au net, paroles et musique, Pindare devait en écrire ou en faire écrire plusieurs copies (...)". Há posições mais ou menos radicais no que concerne a crença do uso da escrita por Píndaro, para a primeira $v$, por exemplo, Hubbard (1985): "For Pindar, writing is intimately bound up with the very process of thought"; para a segunda, sobretudo Nagy (1990) e Wells (2009). Grifo meu em todas as passagens. 
justamente por se dar em um nível subconsciente, e, não raro, é sentido como algo sobrenatural ou como um dom com o qual se nasce ${ }^{72}$. É nesses termos que o grande poeta-xamã Orpingalik explica o processo de nascimento de canções ao explorador do Ártico Knud Rasmussen:

As canções são pensamentos, cantadas com a respiração quando as pessoas são movidas por grandes forças e a fala comum já não serve mais.

O homem é movido da mesma forma que um pedaço de gelo navega de um lado para o outro na corrente. Seus pensamentos são direcionados por uma força que se move quando ele sente alegria, quando ele sente medo, quando ele sente tristeza. Os pensamentos podem invadi-lo como uma inundação, fazendo com que respire com dificuldade e que seu coração pule. Alguma coisa, como uma piora no tempo, o manterá inerte. E então algo acontecerá que nós, que sempre nos pensamos pequenos, sentir-nos-emos ainda menores. E temeremos usar as palavras. Quando então as palavras que queremos usar brotam por si mesmas, tem-se uma canção. ${ }^{73}$

O processo de composição entre os esquimó ${ }^{74}$ do Alasca é descrito de maneira similar, ênfase sendo dada em como é essencial que o poeta se sente imóvel e em silêncio a espera das palavras, que, quando prontas, "tomam forma na mente dos homens e se erguem como bolhas das profundezas do oceano; bolhas que procuram o ar para explodirem na luz"75, esse processo deve acontecer em total solidão, no escuro, em um ato de completa concentração $\operatorname{artística~}^{76}$. Normalmente a composição pode se dar em longas caminhadas solitárias e, de acordo com o relato de Rasmussen ${ }^{77}$, frequentemente envolve um grande esforço por parte do poeta para unir as palavras de uma maneira tão habilidosa de modo que "haja melodia nelas, ao mesmo tempo que sejam pertinentes quanto ao sentido", o que pode fazer com que um homem que queira compor uma canção tenha que "andar de um lado para o outro (...) arrumando as palavras ao mesmo tempo em que grunhe uma melodia que ele mesmo também precisa compor"78.

Uma outra forma com a qual o poeta oral se engaja com a tradição da qual faz parte é a relação que mantém com o vocabulário e a gramática dessa tradição, que normalmente se revelam na obra poética como características que implicam uma sacralização, arcaização ou artificialização face ao vernáculo, o que permite que o tempo da performance desloque o público do hic et nunc do mundo cotidiano para o espaço onde o poeta domina a cena e dita as regras. Aqui, mais uma vez, o sentido se desloca do verbal para o ritual e a lógica do discurso pedestre cede espaço ao pulsar cíclico do mito. Muitas vezes a linguagem desvia tanto de seu uso corrente, seja no eixo sintagmático quanto no paradigmático, que são necessários intérpretes para elucidar o sentido oculto pela linguagem poética, como é o caso dos panegíricos de algumas etnias da África ou da linguagem altamente sacraliza-

72 V. nota 64, acima.

73 Rasmussen, 1931, p. 321 apud Finnegan (1980, p. 83)

74 Embora sentido como pejorativo no Canadá, "esquimó" deve ser preferido a "Inuíte" uma vez que engloba não somente estes mas também os povos Iupic da Sibéria e do Alasca.

75 Freuchen, 1962, p. 280-1, apud Finnegan (2017 [1977]), p. 83.

76 Note o paralelo com a tradição grega de iniciação de poetas como Hesíodo, Arquíloco e Píndaro, entre outros, acontecida em locais ermos.

77 Apud Finnegan (2017 [1977]), p. 83

78 Idem. 
da do Ulahingan, o poema épico dos Manobos do sul das Filipinas ${ }^{79}$. Outra vez, o paralelo grego pode ser mais bem ilustrado por Píndaro que, ciente da complexidade e dificuldade de seus poemas, diz, na Olímpica 2, vv. 82-8 (Snell-Maehler):

\author{
Muitas são-me as setas \\ velozes sob o braço, \\ dentro da aljava, \\ vozeantes aos entendidos, mas \\ para o resto intérpretes \\ há que se ter. Poeta é quem muito \\ sabe de nascença, \\ já os loquazes aprendizes \\ em algazarra como corvos \\ em dupla inânias grasnam \\ face ao divo pássaro de Zeus. ${ }^{80}$
}

Normalmente o vocabulário do poeta oral tende a se especializar em virtude da função subordinada que o plano do conteúdo toma em relação ao da forma, o que está em concordância com a natureza monumental da poesia que discutimos mais acima. Isso aconteceu, por exemplo, com o hexâmetro: para atender ao princípio de extensão vigente no sistema esquemático da linguagem épica, os aedos, em um processo muito lento de evolução da dicção hexamétrica, naturalmente foram substituindo aquelas palavras e formas de seu vocabulário local por outras de outros cantores com os quais iam entrando em contato e que tinham o seu próprio sistema organizado de acordo com o seu dialeto. Dessa forma, constrangida por um metro que em muito dista da fala, bem como pelos temas típicos da épica, surgiu a Kunstsprache, ou "linguarte" homérica, um amálgama de dialetos construída sobre uma base jônico-eólica ${ }^{81}$.

É notável, no entanto, que a mentalidade quirógrafa, centrada no registro e no documento, mais do que na canção e na realidade da performance, tenha prestado pouca atenção na motivação prosódica que a obra vocal eleva ao princípio capital da composição poética e que exerce uma força seletiva sobre a escolha do vocabulário poético que estará disponível a cada executante em uma determinada tradição, encobrindo ou descobrindo zonas de possibilidade entre as quais o poeta se move habilmente, quase ou, mesmo, sem o perceber, mas que constituem o seu "estilo" próprio, a que seus seguidores e sua audiência são tão sensíveis, como vimos acima. É a prosódia, nesse sentido, a responsável pela estilização e pela regularização do vocabulário poético tanto no plano do som, por meio da seleção das palavras, quanto no do ritmo, por meio de sua colocação. Assim, o primeiro passo de qualquer um que queira entender uma tradição poética é começar justamente pelo estudo de sua prosódia, a qual figura proeminente na abertura, por exemplo, de qualquer manual de métrica grega ou latina.

Para Zumthor (2010), a prosódia "refere-se à própria pré-história do texto dito ou cantado, à sua gênese pré-articulatória, interiorizada em forma de eco", e essa é a razão por que

79 Cf. Zumthor (2010), p. 154.

80 Discuto a relevância dessa passagem para se entender a poética pindárica em Brose (2020).

81 Discuto o hexâmetro grego em detalhes em Brose (2015). 
A maior parte das performances, em qualquer contexto cultural, começa por um prelúdio não vocal, batida de um objeto, passo de dança, medida musical preliminar: expõe-se assim o cenário onde vai se desenrolar a voz. Fundamentalmente, a poesia oral só tem regras prosódicas. Okpewho, a propósito dos gêneros africanos, chega a confirmar que esta poesia não tem por função transmitir conteúdos inteligíveis, mas apenas sons e ritmos. Paradoxo, mas não inverdade. $O$ ritmo é sentido, intraduzivel em língua por outros meios [grifo meu]. ${ }^{82}$

O que nos leva à questão principal do ritmo na poesia, que, como o queria Maiakovski, é uma espécie de força magnética do poema ${ }^{83}$. É preciso, aqui, distinguir entre ritmo e metro, frequentemente confundidos. O ritmo é a expressão do metro enquanto ato, e só existe em performance. O metro, por outro lado, é a matriz conceitual do ritmo, ele expressa todas as suas possibilidades, mas, por si só, não tem qualquer existência objetiva e, ainda que o ritmo possa ser daí deduzido, há sempre uma parcela de interpretação, que afeta o resultado final.

Não se tira daí, contudo, a conclusão de que o metro é que faz o ritmo, muito pelo contrário. A estilização progressiva dos ritmos e o uso constante de certos padrões rítmicos leva a fixação de determinadas possibilidades de movimento que se traduzem em formas métricas. Para ter alguma utilidade ao poeta, o metro precisa ter uma certa flexibilidade ou vacância, para usar o termo consagrado por Zumthor, e isso mesmo nas formas métricas mais estilizadas e esquemáticas, como o hexâmetro ou os trímetros e tetrâmetros (jâmbicos ou trocaicos) entre os gregos, quanto o mais em suas formas não estíquicas.

Dessa forma, por projetar o ritmo no futuro através de uma matriz de possibilidades, o metro permite que tanto os cantores como os dançarinos intuam e realizem expectativas rítmicas de modo ordenado. Uma vez, portanto, que ele é uma abstração das possibilidades do ritmo, qualquer perturbação, por menor que seja, é sentida forte e imediatamente por qualquer audiência ${ }^{84}$, daí o efeito estabilizador que o ritmo confere à canção e que é facilmente identificável nos metros mais simples, como os estíquicos, mas que também é sentido naqueles que apresentam grande variabilidade e complexidade como os não estíquicos e assinartéticos, isto é, formados por unidades de tempos díspares.

Não é necessário, porém, recorrer às assim chamadas "línguas mortas" para entender o poder do ritmo na criação e na estabilização das formas poéticas, basta que pensemos, por exemplo (e feitas as devidas concessões à passagem de um sistema morônico a outro, tônico), nos ritmos herdado do latim pelas línguas românicas, praticamente idênticos às formas cultivadas pela literatura do Baixo Império e cujos sistemas se mantiveram quase que inalterados durante toda a Idade Média, chegando até as portas do século XX, quando

82 Zumthor (2010), p. 184. Compare com o prelúdio da $1^{\text {a }}$ Ode Pítica de Píndaro, em que uma concepção semelhante é expressa: "Aurilavrada lira de Apolo | e das Musas dos cachos de violeta, | valedoura posse, | a que passo de dança escuta, princípio de festa, $\mid$ os aedos obedecem seus sinais $\mid$ sempre que, dos proêmios o introito | que os coros guiam, reverberando, soas".

83 "Rhythm is the basic force and the basic energy of poetry. It cannot be explained, it can only be described, like the effects of magnetism or electricity. Magnetism and electricity are forms of energy. The rhythm may be identical in many poems, even in everything the poet has written, but this doesn't make that work uniform, since rhythm can be so complex and difficult of formulation that the poet may totally fail to achieve it in a number of major works". Maiakovski, How are verses to be made? in Gorky (2000), p. 145.

$84 \mathrm{O}$ escólio à Olímpica 2.48 de Píndaro (Drachmann, p. 73, O. 2, 48c, e) nos conta, por exemplo, que Aristófanes de Bizâncio teria "atetizado", isto é, considerado como espúrio, o último colon da segunda estrofe

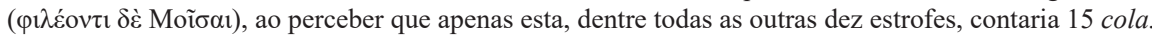


foram finalmente deslocados de sua centralidade pelas novas formas rítmicas do verso livre. O poder encantatório e atrativo (é magnetismo) do ritmo se espalha mesmo entre línguas e tradições completamente distintas, como foi o caso dos trovadores occitânicos, que, mesmo sem conhecer o árabe, foram buscar nas formas tradicionais praticadas por aqueles poetas, outras formas de versificação, como o ghazal, que adaptaram ao seu próprio fazer poético. Essa influência mútua, aliás, foi, aparentemente a regra entre as línguas indo-europeias e não é difícil ver nos metros gregos formas equivalentes ao dos metros indianos, como faz genialmente Nagy em um trabalho ainda pouco considerado ${ }^{85}$.

O ritmo poético, além disso, surge naturalmente a partir da estilização progressiva dos ritmos da fala cotidiana ${ }^{86} \mathrm{e}$, portanto, é tão variável quanto sejam as mais diferentes prosódias que as línguas do mundo possam ter. Aqui, novamente, é preciso reconhecer a diversidade e abrir mão de qualquer tipo de topologia que pudesse nos fornecer uma chave geral com a qual analisar as mais diversas tradições rítmicas. De acordo com Zumthor $^{87}$, poderíamos distinguir sistemas rítmicos baseados:

1. na quantidade silábica, em virtude de esquemas de alternância breve-longa, mais ou menos complexos (sistema morônico);

2. na distribuição das tonalidades, geralmente combinada com um outro elemento, silabismo ou aliteração;

3. no acento, combinado ou não com uma conta silábica (sistema tônico, como o da maior parte das línguas europeias);

4. no paralelismo lexical ou sintático (salmos bíblicos, izibonga zulu, Ulahingan filipino);

5. no número de sílabas, normalmente associado a uma outra regra distributiva relativa aos acentos e aos tons. Pode ser variável (verso épico tibetano) ou estrito (octossílabo do Romancero).

Uma consequência importante é que, no nível da forma, esses sistemas não são traduzíveis entre si, uma quimera muitas vezes perseguida por tradutores que almejam "reproduzir" o metro da língua de partida em uma determinada língua de chegada, quando se pode almejar, no máximo, a uma equivalência intersistêmica. O metro de duas línguas que operam a partir de sistemas prosódicos distintos raramente pode ser reproduzido em tradução porque não é possível transladar para a língua de chegada uma característica prosódica que lhe é estranha, como, por exemplo, a quantidade a uma língua que, como o português, dela não faz uso em seu sistema de versificação; nem no faz, a bem da verdade, em seu sistema fonêmico, posto que, ainda que sílabas acentuadas sejam pronunciadas de uma forma levemente alongada ${ }^{88}$, essa quantidade, por não ser fonemicamente significante, não é normalmente percebida pelo falante. O contrário, aliás, também pode ocorrer: normalmente a quantidade é sentida como intensidade em português, o que não raro se constitui num empecilho aos seus falantes para reproduzir corretamente o acento melódico do grego sem nem lhe dar caráter intensivo nem alongar, quando breve, a sílaba sobre a qual ele incide.

85 Nagy (1974).

86 Nagy (1991), pp. 45-51 (a partir do parágrafo 53 na versão em linha).

87 Zumthor (2010), p. 192.

88 Cristófaro (2019), p. 102 para os valores médios. 
Por outro lado, se o ritmo se realiza apenas em performance, qual seria o sentido de tentar reproduzi-lo no papel $?^{89}$ Como se vê, a mente quirógrafa nos prepara armadilhas e, nelas, nos faz cair sem que muitas vezes percebamos.

De fato, qualquer ritmo pode ser imposto a qualquer poema que seja executado em performance $^{90}$. Mesmo um texto prosaico pode ter suas relações alteradas de modo a se submeter ao ritmo. Essa realidade, aliás, teve um grande impacto no fazer poético do final da Grécia Clássica, com o advento da Nova Música e o relaxamento cada vez maior conferido à relação de tempo entre sílaba e nota musical, e não podemos deixar de imaginar se não estaria, justamente, relacionado à desestruturação do sistema morônico da língua. Assim, se o tradutor deseja reproduzir, por exemplo, os ritmos da poesia grega arcaica, que é indiscutivelmente oral do ponto de vista da performance, só lhe resta uma única alternativa: musicá-los; jogá-los outra vez na performance, restituir-lhes a voz que perderam e experimentar com os seus metros a fim de encontrarmos um ritmo que possa ser plausível. Isso, aliás, no caso da poesia grega não é nem difícil, nem impossível, como demonstram um série de iniciativas recentes nesse sentido ${ }^{91}$.

Quanto ao modo da performance que, atendo-nos ao sistema zumthoriano, é a segunda dimensão mais importante, ao lado da prosódia, da obra vocal, ele pode se apresentar em formas diferentes na mais diversas culturas, cujas conceitualizações bastante específicas determinam noções que podem nos parecer claríssimas e universais em sua superfície, como aquelas de "fala", "recitação" e "canto", mas que revelam particularidades e pontos de descontinuidade ou interseção quando comparadas com sua realidade em outras culturas:

O meio cultural condiciona o sentimento que cada um tem de suas diferenças. O que a voz do griô africano profere não é, para seu grupo étnico, nem fala, nem canto, mas enunciação às vezes atraente e misteriosa, por onde transitam forças talvez perigosas. Os blues, que na prática popular do sul dos Estados Unidos, por oposição aos outros, são designados como talking, constituem um discurso de ritmo acentual forte, passando imperceptivelmente a episódios cantados, certamente distintos do falar comum, porém mais ou menos de acordo com os costumes locais. O que aqui passa por canto, em outro lugar será fala barulhenta. Empiricamente, admitiremos a existência, não de duas, mas de três modalidades: a voz falada (dito), o recitativo escandido ou salmodia (...), e o canto melódico. Os liturgistas medievais utilizavam uma escala semelhante, limitando, contudo, a extensão do primeiro termo, recitativo, ao dito poetizado por um ritmo artificial. [grifo meu] ${ }^{92}$

O problema não está em se definir categorias, mas em identificar o limite entre elas, admitindo-se sempre um espectro de possibilidades e imbricamentos. Uma proposição inicial, no entanto, e que, de certa forma, é ecoada também por Zumthor e Finnegan é o de que a poesia, por ser um discurso marcado, se afigura sempre como canto na cultura de quem a

89 Não está em questão aqui o ritmo pictórico da poesia concreta, uma discussão que extrapolaria o escopo desse artigo.

90 Cf. Zumthor (2010), p. 186, "Cada performance cria assim seu próprio sistema rítmico, ainda que as unidades utilizadas para o construir permaneçam da mesma natureza em todos os casos".

91 Como provam os diversos ensembles de música grega antiga que começaram surgir a partir da década de 90. Entre nós, cabe ressaltar o trabalho do grupo Pecora Loca, por exemplo, e as performances produzidas por Marcelo Tápia e por Carlos Leonardo Bonturim Antunes (UFRGS), entre outros.

92 Zumthor (2010), p. 200-1. Sobre isso também, Nagy (1990), p. 20 seq. $C f$. com a distinção de fala e canto em Aristoxeno, mais abaixo. 
pratica em performance, mesmo que relativamente não seja. Claramente, a fronteira oscila não apenas de acordo com as amplitudes que esta ou aquela cultura admite que a voz chegue antes de considerá-la canto, o que mais uma vez não admite generalizações, mas também na maneira como a voz opera de maneira diferente os intervalos melódicos. Para Aristoxeno (Harm. 1.8-10), por exemplo, "canto" diferenciava-se de "fala" precisamente porque nesta eles são contínuos ( $\sigma v v \varepsilon \chi \varepsilon ́ \varsigma)$; ao passo que, naquela, interespacejados ( $\delta 1 \alpha \sigma \tau \eta \mu \alpha \tau 1 \kappa o i ́)$.

Muitas vezes o canto está ligado a atividades específicas, mormente rituais, das quais não pode se dissociar, como o foi certamente o caso dos gregos, cujas formas poéticas e modos musicais foram apropriados pelo cristianismo e subsistem até hoje na prece, no hino e nos modos musicais litúrgicos, sobretudo na Igreja Ortodoxa. Tamanha foi a importância da forma poética para a preservação do conhecimento que, como nota Havelock (1963), os gregos pré-socráticos não podiam conceber outra forma de difundir sua filosofia, tratados médicos e físicos senão na forma altamente estilizada do hexâmetro homérico. Contemporaneamente, também entre os Manobos, todo discurso sagrado se realiza na forma de canto de uma maneira tão marcada que, mesmo entre aqueles que se cristianizaram, as preces católicas são cantadas com as melodias do Ulahingan, ao invés de serem ditas. Assim também o foi com toda cultura védica, cujo conhecimento sagrado foi preservado na forma rítmica e musical do $R g$-, do Sama- e do Yajurveda.

Além disso, o modo da performance não comporta exclusões mútuas. É totalmente concebível que falado, recitado e cantado se mesclem e se complementem, uma alternância, aliás, que está frequentemente associada a significados, tanto tradicionais quanto episódicos, muito bem marcados pela cultura onde as formas poéticas permitem esse jogo e encontram amparo nas expectativas do público, que pode decodificá-los adequadamente.

O griô gambiano Amadou Jeebaate, ao executar um episódio do Soundiata, utiliza dois modos de performance distintos, o recitativo com acompanhamento musical e o canto, sempre em um dialeto distinto do recitativo. Mesmo assim, algumas partes do recitativo podem, frequentemente, ser cantadas no mesmo dialeto empregado no canto, porém de maneira parentética, a intervalos igualmente espaçados, com a função específica de se enunciar um elogio a determinado personagem ${ }^{93}$. Algo semelhante se dá no teatro indiano clássico, no qual, de acordo com o Natyasastra (Tratado sobre o Teatro), as canções (dhruva) era composta em prakrti (isto é, o vernáculo utilizado nas vilas, em oposição à língua gramatical da literatura, o sânscrito, ou língua "perfeita", samskrta), e, enquanto a maior parte das falas era compostas nos ritmos da prosa, há inúmeras inserções de versos ao longo de uma peça, cujas funções e metros variam enormemente. Nas primeiras trinta e cinco estrofes do Śākuntala de Kālidāsa, por exemplo, são empregados cerca de onze esquemas métricos diferentes ${ }^{94}$. Finalmente, para trazermos o exemplo para um ambiente familiar, é exatamente o que se passa com a tragédia e a comédia gregas, com a sua alternância de metros e dialetos que marcam ou recitativos ou passagens líricas e que, além disso, parecem fazer referência a gêneros poéticos extrínsecos, como o lamento e o epinício ${ }^{95}$.

Um outro aspecto do modo da execução durante a performance diz respeito à dimensão musical, tanto intrínseca quanto extrínseca à obra vocal, em face da qual, novamente, muitas culturas reagiram e reagem de maneiras diferentes. É inegável, no entanto, o valor

93 Zumthor (2010), p. 203.

94 F. Richmond, Suggestions for Directors of Sanskrit Plays, in Van e Brandon (1993), p. 96.

95 Sobre isso, Swift (2010). 
estabilizador que a melodia tem na fixação de um texto pela memória, mas seu valor é sentido de maneira diferente de acordo com a macroforma do discurso.

Por dimensão musical intrínseca entendo aquelas culturas em que a própria língua fornece um primeiro padrão melódico a partir do qual, por meio de uma estilização e abstração progressiva da linha melódica dos próprios enunciados, se desenvolve uma música "de acompanhamento" que frequentemente é transferida para algum instrumento que dê suporte à voz, como no caso do grego. Por dimensão musical extrínseca, por outro lado, entendo aquelas culturas ou tradições poéticas na qual o acompanhamento musical é sobreposto à voz, seja porque a própria língua carece de um sistema melódico marcado fonemicamente, isto é, em que diferenças de tom produzam pares mínimos que alterem o sentido, seja porque a melodia da voz e aquela da música tenham se dissociado.

Por vezes as macroformas dos discursos poéticos, a saber, o que se entende, frequentemente por "gêneros", determinam que tipo de relação se estabelecerá entre o discurso poético e a música. Na narrativa épica tibetana, conhecida como Ge-Sar, há o recurso ao que identificaríamos com uma espécie de leitmotiv: aí cada personagem tem suas falas marcadas por treze tipos diferentes de timbres vocais. Entre os gregos, alguns tipos de canções pareciam estar associadas a acompanhamentos específicos, como, por exemplo, o lamento, ao aulos, e a épica e a hínica homérica, à lira. Da mesma forma, algumas melodias fixas (vó $\mu$ or) estavam associadas a determinadas formas poéticas ${ }^{96}$. Novamente aqui, no teatro indiano, há um paralelo interessante com o grego, já que diferentes tipos de instrumentos musicais são usados de forma marcada em diferentes gêneros, e as escalas musicais ( $r \bar{a} g a$ ) são utilizadas, no drama clássico, para se induzir, na plateia, algum tipo de emoção específica.

Há, portanto, diferentes formas através das quais a oralidade deixa sua marca no texto escrito e por meio das quais se revela. O estudo da oralidade formal, sobretudo a partir da teoria parriana aplicada a Homero, foi um começo importante para uma tomada de consciência acerca da dimensão oral da literatura grega antiga que, como tentamos argumentar nesse artigo, é, em sentido mais preciso, uma oratura.

Há outros pontos de vantagem a partir dos quais se pode reconhecer uma oralidade conceitual em textos que não necessariamente se adequam à teoria formular e foi meu objetivo nesse artigo apresentar alguns deles. Parece-me, acima de tudo, que os Estudos Clássicos têm muito a ganhar de abordagens comparatistas e multidisciplinares, como podem mostrar as descobertas, feitas por pesquisadores, alguns mencionados neste artigo, que abandonaram a ortodoxia da Filologia Clássica e o seu apego irredutível à unidimensionalidade do texto.

\section{Considerações Finais}

Há um imenso trabalho ainda a ser feito e eu gostaria de finalizar esse artigo apontando algumas áreas em que o estudo da oratura grega antiga poderia prosseguir para além da épica, onde um enorme progresso foi alcançado no séc. XX, mas cujos resultados não conseguiram se difundir com o vigor necessário para outras formas prosaicas ou poéticas da oratura grega antiga, como a retórica, o drama ático e a lírica. Na historiografia, uma área que, mais do que qualquer outra, se define implicitamente a partir do estudo da escrita, o

96 Sobre isso, Corrêa (2008). 
estudo da oralidade em Heródoto avançou consideravelmente, mas Tucídides ainda é visto em grande parte como um escritor cuja sofisticação não poderia jamais ter surgido em um contexto oral, uma suposição que, espero, não seja mais tão inabalável ao leitor deste artigo.

Num nível ainda mais fundamental, uma gramática que reconheça, nas muitas estruturas excepcionais do grego arcaico e clássico, características de uma língua otimizada para a fala e ainda pouco impactada pela escrita, poderia revolucionar o modo como novos helenistas aprendem e veem essa língua. Embora já existam muitos estudos linguísticos nesse sentido, uma sistematização desse conhecimento seria uma enorme contribuição aos Estudos Clássicos.

Um último caveat faz-se necessário: não pretendi, com esse artigo, negar ou pôr em dúvida que o estudo literário da oratura grega arcaica não tenha legitimidade ou valor, até mesmo porque a obra vocal da Antiguidade se dá, já no período helenístico, no contexto de uma literacia bastante avançada, o que atesta a própria proliferação de bibliotecas pelo mundo antigo, como as de Alexandria, Pérgamo, Herculano etc. Também precisamos considerar que a recepção dessa oratura acontece, em nossa cultura, a partir do estatuto da literacia, isto é, como literatura. Não obstante, porque a literacia se desenvolve a partir da oracia, o estudo literário de uma oratura deveria sempre ter em perspectiva essa baliza diacrônica para, a partir daí, poder seguir livremente. Negligenciar, dessa forma, essa dimensão oral pré-existente da, agora, literatura grega normalmente conduz a inúmeros equívocos e distorções, alguns dos quais tivemos a oportunidade de examinar neste artigo.

A Filologia Clássica, nascida a partir do paradigma da literacia, precisa, portanto, de ampliar seu olhar para as outras dimensões fundantes do texto se quiser ser capaz de continuar avançando em problemas teóricos a ele relacionados.

\section{Referências}

AGÓCS, P.; CAREY, C.; RAWLES, R., Eds. Reading the Victory Ode. Cambridge: Cambridge University Press. 2012.

ANDRZEJEWSKI, B. W.; LEWIS, I. M. Somali poetry: an introduction. Clarendon Press, 1964.

BAKKER, E. J. Poetry in Speech: Orality and Homeric Discourse. Ithaca/ London: Cornell University Press, 1997.

BATTISTELLA, E. L. The Logic of Markedness. Oxford: Oxford University Press, 1996.

BOILEAU, N. L'art poétique. Paris: Aug. Delalain, 1815.

BRANDÃO, J., L. Antiga Musa: arqueologia da ficção. Belo Horizonte: Relicário, 2015.

BROSE, R. D. Da fôrma às formas: metro, ritmo e tradução do hexâmetro. Cadernos de Tradução (UFSC), v. 35, n. 2, p. 124-160, 2015.

. Translating Pindar as Oral Poetry: the role of a hermeneutics of performance. In:

AGNETA, M. e CERCER, L. (Ed.). Textperformance und Kulturtransfer. Band 6. St.

Ingbert: Röhrig Universitätsverlag, 2021.

CORRÊA, P. D. C. Hamonia: mito e música na Grécia antiga. 2a . São Paulo:

Humanitas, 2008.

CRISTÓFARO SILVA, T. et al. Fonética Acústica: os sons do português brasileiro.

São Paulo: Contexto, 2019. 
DODDS, E. R. The Greeks and the Irrational. University of California Press, 1966.

DRACHMANN, A. B., Ed. Scholia Vetera in Pindari Carmina. Leipzig: Teubner, 1903.

EISENSTEIN, E. L. The Printing Press as an Agent of Change. Cambridge University Press, 1980.

EVANS, V. A Glossary of Cognitive Linguistics. Edinburgh: Edinburgh University Press, 2007.

FAUCONNIER, G. Mental Spaces. Cambridge, Massachussetts: MIT Press, 1985.

FILLMORE, C. J. Frame Semantics. In: GEERAERTS, D. (Ed.). Cognitive Linguistics: basic readings. Berlin: W. de Gruyter, v.34, 2006. p.373-397. (Cognitive Linguistics Research).

FINNEGAN, R. Oral Traditions and the Verbal Art: A guide to research practices. London e New York: Routledge, 2005 [1992].

. Oral Poetry. Eugene: Wipf and Stock, 2017 [1977].

. Oral Literature In Africa. Open Book Publishers, 1982.

FOLEY, J. M. Immanent Art. From Structure to Meaning in Traditional Oral Epic.

Bloomington and Indianapolis: Indiana University Press, 1991

GOODY, J.; WATT, I. The Consequences of Literacy. Comparative Studies in Society

and History, v. 5, n. 3, p. 304-345, 4/1/1963 1963.

GORKY, M.; MAYAKOVSKY, V.; MILLER, A. On the Art and Craft of Writing.

University Press of the Pacific, 2000.

HAMILTON, J. T. Soliciting Darkness: Pindar, Obscurity, and the Classical Tradition.

Massachusetts: Harvard University Press, 2003.

HAVELOCK, E. A. Preface to Plato. Harvard University Press, 1963.

. The Oral-literate equation: a formula for the modern mind. In: OLSON, D. R. e TORRANCE, N. (Ed.). Literacy and Orality. Cambridge: Cambridge University Press, 1991. p.11-27.

HJELMSLEV, L. Prolegomena to a theory of language. University of Wisconsin Press, 1961.

HUBBARD, T. K. The Pindaric Mind: A Study of Logical Structure in Early Greek Poetry. Mnemosyne, Supplements, Volume: 85. Leiden: Brill, 1985.

HUMMEL, P. La syntaxe de Pindare. Paris: Peeters, 1993.

IRIGOIN, J. Histoire du Texte de Pindare. Paris: Klincksieck, 1952.

JAKOBSON, R. Linguistics and Poetics. In: POMORSKA, K. e RUDY, S. (Ed.).

Language in Literature. Michigan: Belknap Press, 1987. cap. 7, pp. 62-94.

KINTGEN, E. R.; KROLL, B. M.; ROSE, M., (Org.). Perspectives on Literacy:

Southern Illinois University Press. 1988.

KOCH, P.; ÖSTERREICHER, W. Sprache der Nähe - Sprache der Distanz.

Mündlichkeit und Schriftlichkeit im Spannungsfeld von Sprachtheorie und

Sprachgeschichte. Romanistisches Jahrbuch, v. 36, p. 15-43, 1986.

. Funktionale Aspekte der Schriftkultur. In: GRÜNTHER, H. e LUDWIG, O.

(Ed.). Writing and its Use: An interdisciplinary handbook of interdisciplinary research.

Berlin: Mouton de Gruyter, 1994. pp. 587-604.

LAKOFF, G.; JOHNSON, M. Metaphors we Live By. Chicago: The University of

Chicago Press, 1980.

. Women, fire, and dangerous things: what categories reveal about the mind.

Chicago: University of Chicago Press, 1987. 
. Philosophy In The Flesh. New York: Basic Books, 1999.

LANGACKER, R. The Foundations of Cognitive Grammar. Stanford University Press, 1999.

LANGACKER, R. W. Grammar and Conceptualization. Mouton De Gruyter, 1999. 2008 . . Cognitive Grammar: a basic introduction. Oxford: Oxford University Press,

LORD, A. B. The Singer of Tales. New York: Atheneum, 1971 [1969].

MAGNANI, M. D. R. M. Educação e letramento. Ed. UNESP: São Paulo, 2004.

MCLUHAN, M. The Gutemberg Galaxy: the making of the typographic man. Toronto: University of Toronto Press, 1962.

MOST, G. W. The Measures of Praise. Göttingen: 1985.

NAGY, G. Comparative studies in Greek and Indic meter. Harvard University Press, 1974.

. Pindar's Homer. Baltimore: The Johns Hopkins University Press, 1990.

Disponível em linha em: < http://www.press.jhu.edu/books/nagy/PH.html $>$.

OLSON, D. R.; TORRANCE, N. Literacy and Orality. Cambridge University Press, 1991.

ONG. W. Orality and literacy: the technologizing of the word. $3^{\text {a }}$ edição com capítulos adicionais de John Hartley. New York: Routledge, 2002 [1982].

PARRY, A. The Making of Homeric Verse: The Collected Papers of Milman Parry.

Oxford: Oxford University Press, USA, 1971.

SALE, M. The Oral-formulaic theory today. In: WATSON, J. (Ed.). Speaking

Volumes: Orality and Literacy in the Greek and Roman World: Brill, 2001. pp. 53-80.

(Mnemosyne, bibliotheca classica Batava: Supplementum).

SNELL, B.; MAEHLER, H., Eds. Pindari Carmina cum Fragmentis - Pars I: Epinikia,

Pars II: Fragmenta. Indices. Bibliothecae Teubnerianae. Leipzig: Teubner, 1980.

SWIFT, L. Hidden Chorus: Echoes of Genre in Tragic Lyric. Oxford e New York, 2010. THIONG'O, N. Penpoints, Gunpoints, and Dreams: Towards a Critical Theory of the Arts and the State in Africa. Oxford University Press, USA, 1998.

THOMAS, R. Literacy and Orality in Ancient Greece. Cambridge Cambridge

University Press, 1992.

. Pindar's 'difficulty' and the performance of epinician poetry. In: AGÓCS, P.;

CAREY, C., et al (Ed.). Reading the Victory Ode. Cambridge: Cambridge University

Press, 2012. cap. 11, pp. 224-245.

VAN, M. B.; BRANDON, J. R. Sanskrit Drama In Performance. Dehli: Motilal

Banarsidass, 1993.

WAUGH, L. E. Marked and Unmarked: a choice between unequals in semiotic structure. Semiotica, n. 38, p. 299-318, 1982.

WELLS, J. B. Pindar's Verbal Art: An Ethnographic Study of Epinician Style.

Washington: CHS/ Harvard University, 2009.

YOUNG, D. C. Pindaric Criticism. In: CALDER III, W. M. e STERN, J. (Ed.).

Pindaros und Bakchylides. Darmstadt: Wissenschaftliche Buchgeselchaft, v. 2, 1970. cap. 1, p.1-95. (Wege der Forschung).

ZUMTHOR, P. Introdução à Poesia Oral. Trad. de Jerusa Pires Ferreira, Maria Lúcia

Diniz Pochat e Maria Inês de Almeida. Belo Horizonte: UFMG, 2010. 